\title{
A Comparative analysis of Bangladesh Water Management Practice with European Water Framework Directives
}

\author{
Md. Masud Alam ${ }^{1} \&$ Philippe Quevauviller ${ }^{2}$
}

${ }^{1}$ Senior Scientific Officer, Water Resources Planning Organization, Ministry of Water Resources, Bangladesh

${ }^{2}$ Associate Professor, Department of Hydrology and Hydraulic Engineering, Vrije Universiteit Brussel, Belgium

\begin{abstract}
Until 90, water management plans in Bangladesh focused mainly to controlling floods and facilitates drainage and irrigation which were segregate plans, and caused detrimental effects of other sectors such as water supply, sanitation, industry, fisheries plus environmental and other in-stream demands. For avoiding the fragmentation, the country has achieved a remarkable progress in Integrated Water Resources Management (IWRM) activities after the period of 90.The Flood Action Plan (FAP, 1989-1995) was the pioneer of IWRM plan in Bangladesh. In 1995, Government approved The Bangladesh Water and Flood Management Strategy (BWFMS) which was an outcome of FAP. Under the recommendation of BWFMS, Bangladesh prepared NWPo and NWMP which were the holistic and government approved documents for applying integrated water resources practice in Bangladesh.The European Union has a long experience for basin wide integrated water resources management within Europe. The European Parliament and the Council of the European Union established a framework for Community action in the field of water policy in 23 October 2000 European Union's water policies such as the Water Framework Directive (2000/60/EC). The EU's experience (including its 27 Member States) is based on the best scientific knowledge and available technologies. In particular, the Water Framework Directive (2000/60/EC) mainly focuses on river basin management rules and principles. It is recognized that the Water Framework Directive (WFD) might be used as an example for basin wide IWRM implementation and economic development for the developing countries like Bangladesh, taking into account their socio-economic conditions.This study will show that, how the European Union Water Framework Directive (WFD) model can be adapted for the effective implementation of integrated water resources in Bangladesh. A Common Implementation Strategy (CIS) has been depicted for sustainable IWRM in Bangladesh.
\end{abstract}

Keywords: Integrated Water Resources Management (IWRM), Common Implementation Strategy (CIS), Water Framework Directive (WFD) 


\section{INTRODUCTION}

Located in an alluvial deltaic floodplain, Bangladesh faces massive water resources challenges in terms of (i) severe flooding, sedimentation of river channels, and erosion of the riverbanks causing severe social hardships; (ii) scarcity of water during the dry season amidst expanding water demand; (iii) saline intrusion and environmental degradation in particular in the Southwest; (iv) cyclones and tidal surges in coastal areas; and (v) heavy arsenic contamination of groundwater. With dense population, water management is further complicated by diverse and conflicting interests among traditional livelihood activities including agriculture, fisheries, transportation, industries, and water supply, with which poverty is deeply intertwined. Water is also essential for the country's rich and vulnerable natural ecosystems. The Global Climate Change and Upstream withdrawal of water are going to create future challenge in Water Resources Management in Bangladesh. Therefore, it is of paramount importance for the country to manage this critical resource in an integrated and strategic manner while ensuring stakeholder participation.

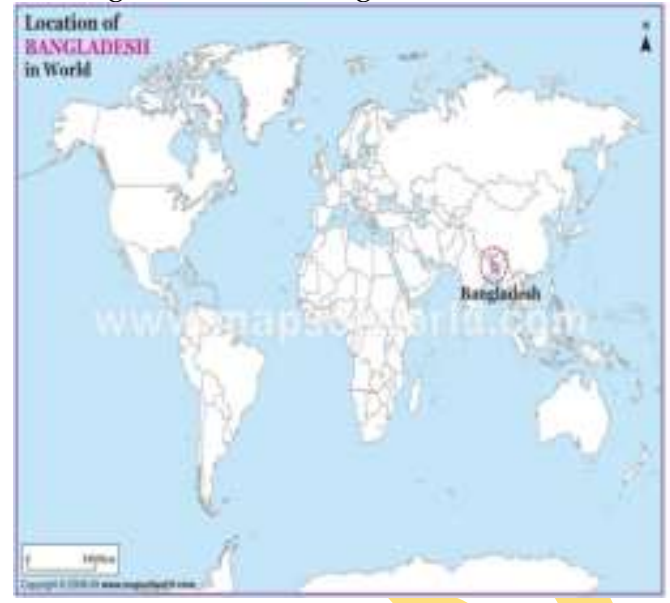

Figure 1: Geographical Location of Bangladesh

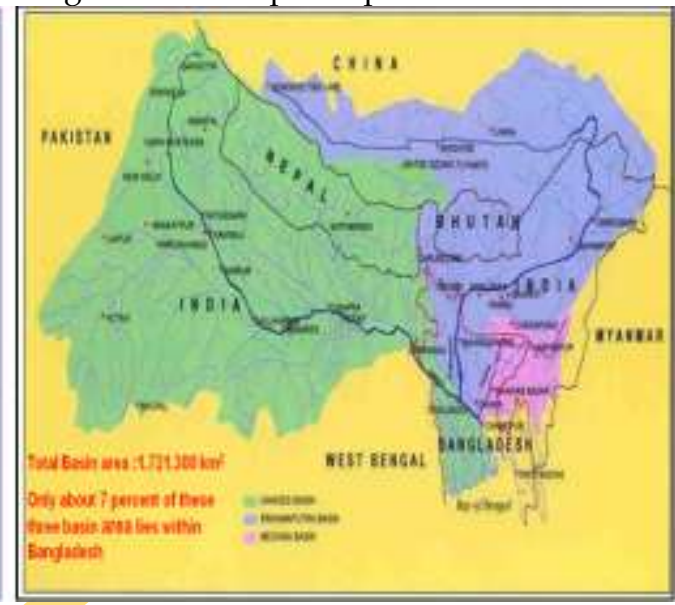

Figure 2: The GBM River Basin (http://www.mapsofworld.com/bangladesh; JRC, Bangladesh- www.jrcb.gov.bd)

For minimizing the adverse impact in Water Sector Bangladesh, the country has done lot of studies and has taken lot of programs chronologically for systematic Water Resources development and Management.

Until 90, the Water Management in Bangladesh were involved mainly to controlling floods and facilitates drainage and irrigation. Lot of detrimental effects were caused in other sectors such as water supply, sanitation, industry, fisheries plus environmental and other in-stream demands (NWPo, 1999). The Earlier Plans were criticised for inadequate policy frameworks and supporting strategies and due to lack of holistic and participatory approach in the water resources planning and also for not addressing the social and environmental impacts of water resources development.

By keeping the global consistency and avoiding the fragmentation in water sector, Bangladesh has achieved a significant progress in IWRM activities after the period of 90. National Water Policy (NWPo, 1999), National Water Management Plan (NWMP, 2001) are the principle guided documents for water management in Bangladesh based on IWRM.

The issue of IWRM is being highlighting globally after the 1990's. Integrated Water Resources Management (IWRM) is defined as the coordinated development and 
management of water, land, and related resources in order to maximise economic and social welfare without compromising the sustainability of vital environmental systems. (GWP, 2000). The IWRM framework (i.e. three E's- Economic efficiency in water use, Equity, Environmental and ecological sustainability ) is based on the Dublin Principles.

The European Union has a long experience for basin wide integrated water resources management within Europe. The European Parliament and the Council of the European Union established a framework for Community action in the field of water policy in 23 October 2000 European Union's water policies such as the Water Framework Directive (2000/60/EC). The EU's experience (including its 27 Member States) is based on the best scientific knowledge and available technologies. In particular, the Water Framework Directive (2000/60/EC) mainly focuses on river basin management rules and principles. It is recognized that the Water Framework Directive (WFD) might be used as an example for basin wide IWRM implementation and economic development for the developing countries, taking into account their socio-economic conditions.

During the past several decades, Government has consistently worked towards proactive and integrated water resource management with the result that a reasonably comprehensive suite of policies has been put in place. Significant changes have also been introduced to service delivery agencies to promote improvements. In general, the concepts of Integrated Water Resource Management promoted by the Global Water Partnership are well reflected in the development of the water sector in Bangladesh. Nevertheless, as described later in this document, the current study emphasizes selected IWRM aspects and identifies means to further promote IWRM. This study will show that, how the European Union Water Framework Directive (WFD) model can be adapted for basin wide integrated planning for a developing country Bangladesh.

\section{Objective}

The overall objective of this study is to compare the Bangladesh Water Management Practice with European Water Framework Directives and evolution of Common Implementation Strategy (CIS) for effective implementation of Integrated Water Resources Management (IWRM) principles in Bangladesh

Specific objectives include:

- $\quad$ To set up online questionnaire surveys to the International Water Expertise for getting more appropriate results related to IWRM.

- To set up an analytical framework methodology for comparison of Bangladesh Water Management Practice with European Water Framework Directives

- To investigate how European Water Framework Directives may be adapted in developing countries like Bangladesh.

- $\quad$ To set up an Common Implementation Strategy (CIS) to expose the best way of water resources management system in Bangladesh and for sustainable development.

\section{ApProach And Methodology}

An online questionnaire survey has been carried out addressing International ( European Union) Water Expertise for getting appropriate information related to this thesis. Also IWRM activities of Bangladesh have been compared with the European Water management system as developed under the EU Water Framework Directive. Steps has been taken how European Union Water Framework Directives (WFD) be adaptive in 
developing countries like Bangladesh. Finally, a Common Implementation Strategy (CIS) has been derived for effective Implementation of IWRM plan in Bangladesh.

\section{SCOPE OF WORK}

\section{Setting up Online Questionnaire Survey}

Table 1: Online Questionnaire format to the International Water Expertise

\begin{tabular}{|l|l|}
\hline Serial No. & Questions \\
\hline 1. & $\begin{array}{l}\text { What is the main sustainable and attracting point of European Water Management } \\
\text { system? }\end{array}$ \\
\hline 2. & $\begin{array}{l}\text { Is WFD quite enough for Integrated Water Resources Planning in Europe? or what } \\
\text { is the next vision of Europe for Integrated water Resources Planning? }\end{array}$ \\
\hline 3. & $\begin{array}{l}\text { What lessons can be acquired from European water management system by } \\
\text { Developing countries for their mainstreaming? }\end{array}$ \\
\hline 4. & $\begin{array}{l}\text { What is the main weak point for Integrated Water Resources Management in } \\
\text { developing countries like Bangladesh? }\end{array}$ \\
\hline 5. & What is the recommends for developing countries IWRM? (if possible) \\
\hline
\end{tabular}

Few reflections about online questionnaire survey on International Water Expertize

Prof. Félix Francés, ffrances@hma.upv.es, Universidad Politecnica de valencia, Spain mentioned that that the most attractive point of European water management is that it is The consideration of the basin as the management unit and the incorporation of the environmental issues. He also stated that WFD may the Integrated Water Resources Planning guideline in Europe. He thinks that the basin must be considered as a management unit and it cannot be divided for Water Resources Management for Sustainable Water Resources Development in Developing countries. In case of IWRM in Bangladesh he recommended that the main problem is the WRM coordination with other countries sharing the administration of the Brahmaputra river basin.

Doctor Anita Meldrum, Anita.Meldrum@gcu.ac.uk, Lecturer/researcher, Glasgow Caledonian University, Scotland, UK mentioned that EU has regulations like the WFD and it has set requirements that member states must comply with and EU has EMS (environmental management systems - ISO 14001 series) that support the delivery of compliance strategies. She further elaborated that WFD is intended to be a way of ensuring integrated water resource management in the EU. As EU is still in the first stage of the implementation of this directive, so EU has to wait if it will work, She also mentioned 'current belief globally ( US, Australia and Canada) is that river basin level management is the way to go, given that there may be usage conflicts between countries that have access to water resources in one basin. EU has to achieve good ecological and chemical water quality by 2015 and then there will be five year plans after that to keep enhancing performance'. For sustainable Water Resources Management in Bangladesh, she emphasized that Bangladesh must consider with the political commitment and availability of knowledge and management physical resources. She elaborated that there has to commitment at government and budget levels to ensuring that those who have to deliver reliable water resources have the capability and resources to do it for the long term, taking into account climate change impacts. 


\section{Setting up Analytical framework methodology (Comparison Bangladesh Water Management Practice with the European Water Framework Directives and Lesson learned)}

The EU Water Framework Directive (WFD, 2000/60/EC) is the main guided and principle document for basin wide integrated water resources management for the European Union including its 27 Member States which is based on best scientific knowledge and available technologies. On the Other hand, the National Water Policy (NWPo 1999) is the main guided and principal document for the implementation of Integrated Water Resources Management (IWRM) in Bangladesh.

Although, WFD is applicable for basin wide integrated water resources planning and management, yet the articles of WFD can be applied for overall implementation of IWRM plan in a country. In this study, The National Water Policy (NWPo 1999), of Bangladesh has been compared to the WFD and the lessons learned from the European water management system have enabled to issue recommendations for possible integration into sustainable water resources management as developed in the Bangladesh.

The salient features of European Water Management system and Bangladesh Water Management have been shown in the following table.

Table 2: Comparison of Bangladesh Water Management practice with the European Union Water Framework Directives

\begin{tabular}{|c|c|}
\hline $\begin{array}{l}\text { European Union Water Framework Directives } \\
(\text { WFD,2000) }\end{array}$ & $\begin{array}{l}\text { Bangladesh Water Management practice (NWPo, } \\
\text { 1999) }\end{array}$ \\
\hline $\begin{array}{l}\text { Coordination of administrative arrangements within } \\
\text { river basin districts } \\
\text { Member States shall identify the individual river } \\
\text { basins lying within their national territory and, } \\
\text { for the purposes of this Directive, shall assign } \\
\text { them to individual river basin districts. and } \\
\text { Member States shall ensure the appropriate } \\
\text { administrative arrangements, including the } \\
\text { identification of the appropriate competent } \\
\text { authority, for the application of the rules of this } \\
\text { Directive within each river basin district lying } \\
\text { within their territory. (WFD, article 3.1,3.2) }\end{array}$ & $\begin{array}{l}\text { Coordination of administrative arrangements within } \\
\text { river basin districts } \\
\text { The Water Resources Planning Organisation } \\
\text { (WARPO) will delineate the hydrological regions of } \\
\text { the country, based on appropriate natural features, for } \\
\text { planning the development of their water resources. } \\
\text { WARPO will prepare, and periodically update, a } \\
\text { National Water Management Plan (NWMP) } \\
\text { addressing the overall resource management issues in } \\
\text { each region and the whole of Bangladesh, and } \\
\text { providing directions for the short, intermediate, and } \\
\text { long runs. (NWPo, article } 4.2 \mathrm{a}, 4.2 \mathrm{~b} \text {.) }\end{array}$ \\
\hline $\begin{array}{l}\text { Environmental objectives } \\
\text { Member States shall implement the necessary } \\
\text { measures for surface waters, groundwater and will } \\
\text { establish the protected areas. 'Good surface water } \\
\text { status' means the status achieved by a surface water } \\
\text { body when both its ecological status and its chemical } \\
\text { status are at least good. 'Good groundwater status' } \\
\text { means the status achieved by a groundwater body } \\
\text { when both its quantitative status and its chemical } \\
\text { status are at least good. (WFD, article } 4 \mathrm{a}, 4 \mathrm{~b}, 4 \mathrm{c} \text { ) }\end{array}$ & $\begin{array}{l}\text { Environmental objectives } \\
\text { The Government will take steps to protect the } \\
\text { water quality and ensure efficiency of its use. The } \\
\text { Government will Strengthen appropriate } \\
\text { monitoring organisations for tracking groundwater } \\
\text { recharge, surface and groundwater use, and } \\
\text { changes in surface and groundwater quality. } \\
\text { (NWPo Article } 4.2 \mathrm{n}, 4.7 \mathrm{f} \text { ) }\end{array}$ \\
\hline $\begin{array}{l}\text { Characteristics of the river basin district, review of the } \\
\text { environmental impact of human activity and economic } \\
\text { analysis of water use } \\
\text { Each Member State shall ensure that for each river } \\
\text { basin district or for the portion of an international } \\
\text { river basin district falling within its territory an } \\
\text { analysis of its characteristics, a review of the } \\
\text { impact of human activity on the status o surface } \\
\text { waters and on groundwater, and an economic } \\
\text { analysis of water use. The analyses and reviews }\end{array}$ & $\begin{array}{l}\text { Characteristics of the hydrological region, review of the } \\
\text { environmental impact of human activity and economic } \\
\text { analysis of water use } \\
\text { National Water Management Plan (NWMP) will } \\
\text { address the overall resource management issues in } \\
\text { each Hydrological region and the whole of } \\
\text { Bangladesh, and will provide directions for the short, } \\
\text { intermediate, and long runs. Water management } \\
\text { agencies and related natural resources departments } \\
\text { will adhere to a formal environmental impact }\end{array}$ \\
\hline
\end{tabular}




\begin{tabular}{|l|}
\hline $\begin{array}{l}\text { European Union Water Framework Directives } \\
\text { (WFD,2000) }\end{array}$ \\
\hline
\end{tabular}

mentioned above shall be reviewed, (WFD, article $5.1,5.2)$.
Bangladesh Water Management practice (NWPo, 1999) assessment (EIA) process, as set out in EIA guidelines and manuals for water sector projects. All relevant analytical procedures and evaluation methods, such as mathematical modelling, physical modelling, costbenefit analysis, risk analysis and multi-criteria decision making are routinely used as part of water resources planning and project appraisal. (NWPo Article $4.2 b, 4.12 b, 4.5 c)$

Waters used for the abstraction of drinking water Waters used for the abstraction of drinking water

Member States shall identify, within each river basin District the all bodies of water used for the abstraction of water intended for human consumption providing more than $10 \mathrm{~m} 3$ a day as an average or serving more than 50 persons and those bodies of water intended for such future use. (WFD, article 7.1)

Monitoring of surface water status, groundwater status and protected areas

Member States shall ensure the establishment of programmes for the monitoring of surface water status, groundwater status and protected areas. (WFD, article 8.1)

Recovery of costs for water services

Member States shall take account of the principle of recovery of the costs of water services, including environmental and resource costs, having regard to the economic analysis and in accordance in particular with the polluter pays principle. (WFD, article 9.1)

The combined approach for point and diffuse sources The Member state shall control the emission and limit the emission value based on best available techniques for the best environmental practices. (WFD, article 10.1, 10.2)

\section{Programme of measures}

Each Member State shall ensure the establishment for each river basin district, or for the part of an international river basin district within its territory, of a programme of measures, in order to achieve the Environmental Objectives (WFD, article 11.1)

Issues which can not be dealt with at Member State level Where a Member State identifies an issue which has an impact on the management of its water but cannot be resolved by that Member State, it may report the issue to the Commission and any other Member State concerned and may make recommendations for the resolution of it. The Commission shall respond to any report or recommendations from Member States within a period of six months. (WFD, article 12.1, 12.2)

River basin management plans
The Government will exercise its water allocation power in identified scarcity zones on the basis of specified priorities and will preserve natural depressions and water bodies in major urban areas for recharge of underground aquifers and rainwater management. (NWPo article 4.3a, 4.6b)

Monitoring of surface water status, groundwater status and protected areas

The Government will strengthen appropriate monitoring organisations for tracking groundwater recharge, surface and groundwater use, and changes in surface and groundwater quality. (NWPo, article 4.7f)

\section{Recovery of costs for water services}

The Government will establish Economic and Financial Management Structure for Water Service and delivery. The Government shall also enforce the "polluter pay" principle in the development of regulatory guidelines for all regulatory actions designed to protect public health and the environment. (NWPo, article 4.12i and 4.14a-g)

The combined approach for point and diffuse sources

Effluent disposal will be monitored by relevant Government agencies to prevent water pollution. Standards of effluent disposal into common watercourses will be set by WARPO in consultation with DOE. (NWPo, article 4.8b, 4.8c)

\section{Programme of measures}

Under the guidence of NWPo, the NWMP has taken 84 programs in 8 clusters. The Prgram has been divided into three broad categories such as Cross- Cutting program, National level program and regional Program-NWPo. Article 4.2b

Issues which can not be dealt with at Organization level Within the macro framework of the NWMP, Sector agencies of the Government and local bodies will prepare and implement subregional and local water-management plans in conformance with the NWMP and approved Government project appraisal guidelines. The Executive Committee of the National Water Resources Council (ECNWRC) will resolve any interagency conflict in this regard. (NWPo, article 4.2d)

River basin management plans




European Union Water Framework Directives
(WFD,2000)

Member States shall ensure that a river basin management plan is produced for each river basin district lying entirely within their territory. In the case of an international river basin district falling entirely within the Community or international river basin district extending beyond the boundaries of the Community, the Member States shall coordinate or endeavour to produce a single river basin management Plan. Where this is not possible, the plan shall at least cover the portion of the international river basin district lying within their territory or territory of the Member State concerned. (WFD, article 13.1, 13.2, 13.3)

Public information and consultation

Member States shall encourage the active involvement of all interested parties in the implementation of this Directive, in particular in the production, review and updating of the river basin management plans. Member States shall ensure that, for each river basin district, they publish the time table, work program, significant water management issue and make available for comments to the public, including users. (WFD, article 14.1)

Strategies against pollution of water

The European Parliament and the Council shall adopt specific measures against pollution of water by individual pollutants or groups of pollutants presenting a significant risk to or via the aquatic environment, including such risks to waters used for the abstraction of drinking water (WFD, article 16.1)

\section{Strategies to prevent and control pollution of}

Groundwater

The European Parliament and the Council shall adopt specific measures to prevent and control groundwater pollution. Such measures shall be aimed at achieving the objective of good groundwater chemical status (WFD, article 17.1)

\section{Commission report}

The Commission shall publish a report of review of progress in the implementation of the Directive at the latest 12 years after the date of entry into force of this Directive and every six years thereafter, and shall submit it to the European Parliament and to the Council. (WFD, article 18.1, 18.2)

Regulatory committee

The Commission shall be assisted by a committee The Committee shall adopt its rules of procedure (WFD, article 21.1, 21.2 )
Bangladesh Water Management practice (NWPo, 1999)

It is the policy of the government to undertake essential steps for realising basin-wide planning for development of the resources of the rivers entering its borders. The Government will endeavour to enter into agreements with co-riparian countries for sharing the waters of international rivers, data exchange, resource planning and long-term management of water resources. While moving towards the attainment of basin-wide plans in the long run, it will also be necessary for Bangladesh to concentrate on the development of individual hydrological areas to meet short and intermediate term requirements. (NWPo article 4.2)

\section{Public information and consultation}

In order to ensure that all stakeholders actively and fruitfully participate in water resources management decision making at all stages, it is the policy of the Government that the "Guidelines for People's Participation (GPP) in Water Development Projects" be adhered to as part of project planning by all institutions and agencies involved in public sector management of water resources. (NWPo article 4.16a)

Strategies against pollution of water

(Not described in NWPo but the Bangladesh Environment Conservation Act,1995 article 13 describes that, 'The Government may, by notification in the official gazette from time to time, formulate and publish environmental guidelines relating to the control and mitigation of environmental pollution, conservation and improvement of the environment').

Strategies to prevent and control pollution of

Groundwater

The Government shall strengthen the regulatory system for agricultural chemicals that pollute ground and surface water, and develop control mechanism for reducing non-point pollution from agro-chemicals. (NWPo article 4.7e)

Reporting to ECNWRC

WARPO will prepare, and periodically update, a National Water Management Plan (NWMP) and will Acting as a "clearing house" for all water sector projects identified by different agencies and reporting to the ECNWRC on their conformity to the NWMP. (NWPo article 4.2b, 5d.v)

Regulatory committee

WARPO will serve as the Executive Secretariat of the ECNWRC and shall provide administrative, technical, and legal support to the ECNWRC.(NWPo article 4.5d.i)

Source: Water Framework Directive (2000/60/EC); NWPo (MoWR, Bangladesh, 1999); 


\section{Setting up EU WFD River Basin Management Planning Adaptation}

The EU Water framework Directive (WFD) has set out arrangements for river basin administration and planning, based on, inter alia, common objectives for water status, and common monitoring and assessment strategies. The initiatives taken for the River Basin Management Planning (RBMP) under the WFD could be a model for the management of water resources over the developing country like Bangladesh. The various components of the River Basin Management Planning (RBMP) have been set up as follows:

Delineation of Hydrological Region in accordance with River Basin Districts (RBDs)

In accordance with NWPo para 4.2, The Water Resources Planning Organization (WARPO)

has delineated the eight hydrological regions of the country, based on appropriate natural features, for planning the development of their water resources. The hydrological regions are Northwest (NW), North Central (NC), Northeast (NE), Southeast (SE), South Central (SC), Southwest (SW), Eastern Hills (EH) and Main Rivers and Estuaries (RE). Hydrological region has been shown in the following figure 3.1.

The government of Bangladesh has to be established a competent authority for each of the hydrological regions to co-ordinate the implementation of the NWPo and NWMP within it. These competent authority will be the branch office of WARPO and WARPO will act as a co-ordinating body for these competent authorities. The competent authority will be responsible for implementing the River Basin Management Plan within each hydrological region designed by NWMP. This theme can be called as decentralization of WARPO, based on hydrological region. The Government of Bangladesh (responsible organization is the Joint River Commission, Bangladesh) will endeavour to enter into agreements with coriparian countries (India, Nepal, China, Bhutan and Mayanmar) for sharing the waters of international rivers, data exchange, resource planning and long-term management of water resources under normal and emergency conditions of flood, drought and water pollution. While moving towards the attainment of basin-wide plans in the long run, it is necessary for Bangladesh to concentrate on the development of these individual hydrological Regions to meet short and intermediate term requirements. This way WARPO will work close contact with JRC for trans-boundary water issue.

Figure 3: Hydrological Regions of Bangladesh

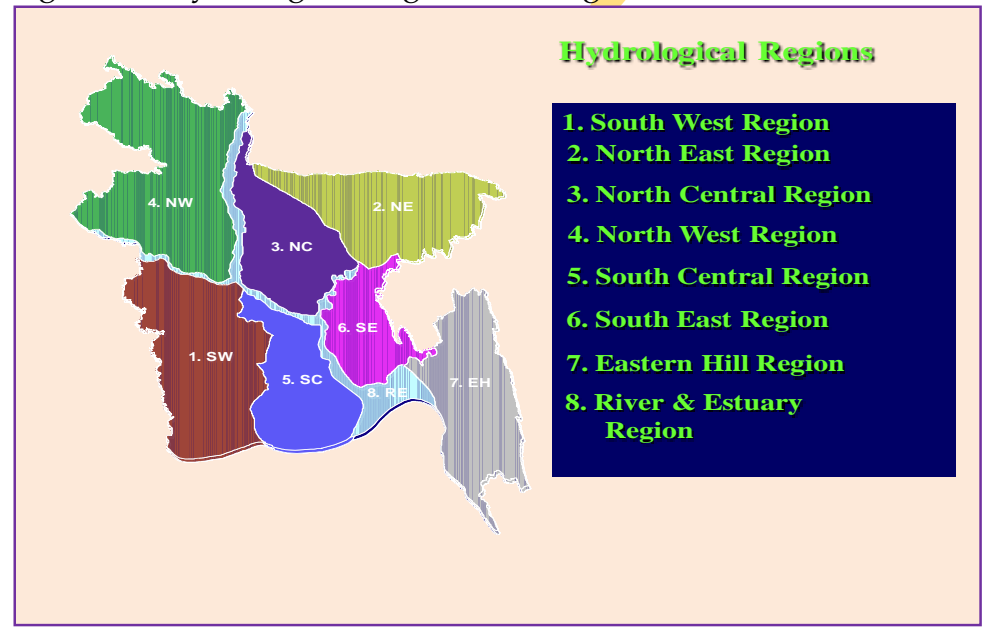

(Source: NWMP, 2004) 
Development of River Basin Management Plan (RBMPs) in each Hydrological Region

WARPO along with the competent authority will prepare, and periodically update, a National Water Management Plan (NWMP) addressing the overall resource management issues in each hydrological region and the whole of Bangladesh, and providing directions for the short, intermediate, and long runs. The plan will be executed by different agencies with guidance of competent authority as determined by the Government from time to time. This is the main mechanism of achieving the co-basin countries environmental objectives and as such, there are a wide range of requirements for what is contained in the River Basin Management Plan:

- Inherent natural characteristics of the river basin in each Hydrological Region

- Environmental monitoring data (water quality and water quantity)

- Details of the impacts of human activity (e.g. point / diffuse pollution, abstractions, flood defence works)

- Analysis of the economic usage of water

- Strategic plan for the achievement of "sustainable water management" goal

Description of the basin characteristics of the Hydrological region

An analysis of the river basin should be carried out by the competent authorities to determine the factors influencing both water quality and water quantity. These analyses would include an assessment of the inherent natural characteristics of each basin, the impact of human activity and the economic usage of water within the basin. It is also require that a thorough review of human activities in basin takes place, including point and diffuse source sources of pollution, abstractions and other human interventions such as flood defence.

Investigation of Impact of human Activities

After characterizing the river basin in each hydrological region, the next task in the planning cycle is to carry out an analysis of the impact of human activity on the waterbodies within each hydrological region, and in particular the identification of the pressures that such activities might be causing. This analysis would need to include the impact of point source pollution, diffuse pollution resulting from land use practice, Development of series of models

\section{Monitoring program}

The surface water monitoring network shall be established and designed by competent authority to provide a coherent and comprehensive overview of ecological status within each river basin and to provide a chemical status of the water bodies, i.e. good or failing to achieve good. For ground water, the competent authority will establish a groundwater monitoring network, which will provide a reliable assessment of the quantitative status of all groundwater bodies or groups of bodies including assessment of the available groundwater resource, and provide a coherent and comprehensive overview of groundwater chemical status within each river basin and detect the presence of long-term anthropogenically induced upward trends in pollutants.

\section{Programme of Measures}

Having carried out the monitoring program of water bodies in the river basin within a Hydrological region, the competent authorities will use this information in developing an 
integrated program of measures. These will be made up of compulsory basic measures such as the licensing of discharges and abstraction, and where necessary the supplementary measures. Supplementary measures will be undertaken if the basic measures are not sufficient to meet the environmental objectives. The Programme of Measures and other detailed information regarding the river basin will be packaged and presented in a document called a River Basin Management Plan in hydrological regions. These plans will be subject to a period of public consultation. River Basin Management will be perodically reviewed and updated.

\section{Setting up appropriate model for real time integration (Initiatives for Common Implementation Strategy)}

The Real time integration could be a possible approach for sustainable water resources management in Bangladesh. An integrated approach for IWRM in Bangladesh is depicted in figure 4 . To ensure equity of water resources over the country, Bangladesh has to work out joint plans for different river basins with other co-riparian countries i.e. India, Nepal, Bhutan and China and Mayanmar. Under the regional co-operations all member countries could be able to take initiatives for Common Implementation Strategy. Along with regional cooperation, the country has to to undertake essential steps for Strengthening the Enabling Environment, the Institutional framework, and management Instrument considering the emerging issues such as climate change, ground water utility, physical and financial resources management, awareness building etc.

Figure 4: Integrated Approach for IWRM in Bangladesh (Common Implementation Strategy)

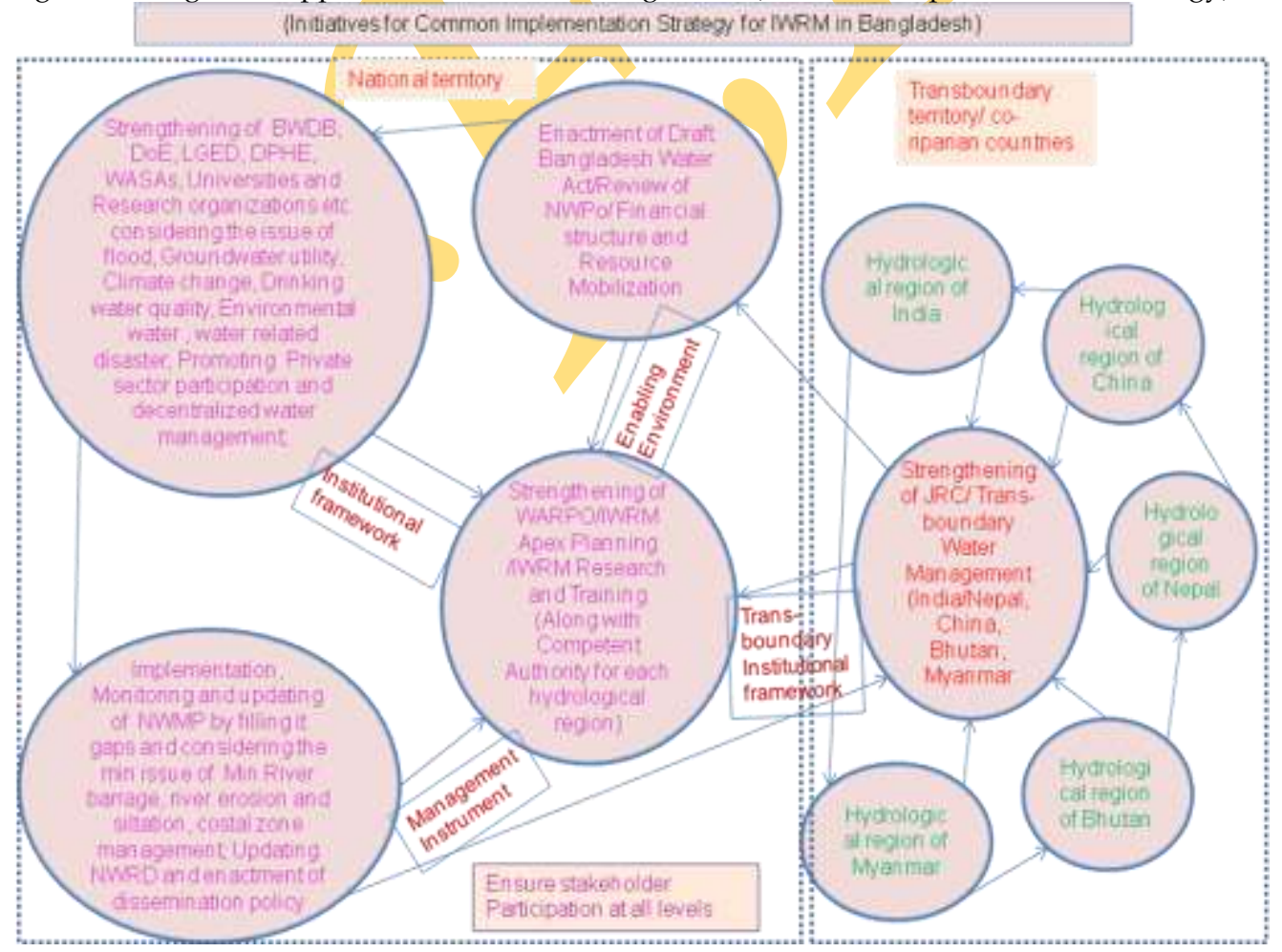




\section{ANALYSIS OF RESULTS Discussion}

International Water Expertise highlighted that the major obstacle for IWRM in Bangladesh are the lack of coordination with co-riparian countries, lack of information and awareness, lack of political willingness, lack of organizational smoothness etc..

International Water Expertise pointed out the attractive point of European Water Management system is that it has carried out according to the natural boundary, and not any political or administrative boundary. Basin has considered as a management unit. For the proper implementation of IWRM in the developing country, they emphasized that the basin must be considered as a management unit.

Questionnaire survey has also shown that for the Proper implementation of IWRM, information, coordination and stakeholder participation is must. University can play a vital role in this regard.

EU is implementing IWRM over the basin considering the priority of the Public Health and Safety i.e. Good status of water bodies (Water quality, and quantity). Strong emphasis has given on Environment, protected areas and aquatic ecology. The technology, proper monitoring, protection of water body, Information, cost recovery system etc. are the salient features of European water management system.

Bangladesh is implementing IWRM plan over the country. Priority has given to the National economic Growth. Strong Emphasis has been given on Environmental Pollution Control. And in case of allocation of water during critical period, the priority has been given by the following order: domestic and municipal uses, non-consumptive uses (e.g. navigation, fisheries and wild-life), sustenance of the river regime, and other consumptive and non-consumptive uses such as irrigation, industry, environment, salinity management, and recreation. Cost recovery of services such as flood control, drainage, irrigation, and wastewater treatment has not been considered adequately in the policy.

In WFD water policy, gender awareness is omitted. There is no clear guideline for the role of women in the provision, management and safeguarding of water whereas women play a pivotal role as providers and users of water and guardians of the living environment. For millions of women around the world, fetching and carrying water is part of their daily work routine (Barua, 2006). Women are responsible not only for themselves, but also for the members of their families and the community at large. It is recognised that women have a particular stake in water management because they are the principal providers and carriers of water, main caretaker of the family's health, and participants in many stages of pre and post harvest activities. Without considering this large part of the people it will be not wise to consider any issue over the country. As women are carriers of water, main users, family health educators, motivators and agents of change, for better and efficient water resources management the role of women must be reflected in the institutional arrangement of water resources.

There is no guideline to encourage and regulate the private sector for the water management in WFD water policy, whereas private sector and NGO's plays a great role in the developing countries. Privatization and public-private participation are among the most important issues that are the focus of different international conferences related to freshwater management.

There is needed to be focus on poverty alleviation in the WFD water policy. IWRM calls for "A blue revolution" to ensure more jobs and more crops per drop of water (GWP, 2000). Agriculture is the world's largest user of water. Water is the essential requirement for all forms of food production. It is estimated that $69 \%$ of worldwide water use is for 
irrigation (http://en.wikipedia.org/wiki/Water_resources).To eradicate poverty, water policies must focus on the agricultural sector. In context of developing country like Bangladesh water resources in the agricultural sector is playing an important role.

In spite of only few drawbacks, Water Framework Directive (WFD) could be a model for the developing countries for the management of water resources based on IWRM principles with the better coordination of transboundary countries. It may be possible to draw lessons from this European initiative that could be appropriate to other river basins across the world. Even though still have to be consider few important matters when WFD policy will apply for water management in the developing countries, but also it could be play great role in twenty first century. Gender awareness, private sector envelopment and poverty allocation still need to be focus when WFD water policy will apply for the developing countries.

In case of Bangladesh, along with the above issues the other things that have to be considered for applying WFD for implementing IWRM plan based on river basin include creation of competent authority for each of the hydrological regions; analysis of human impact on the basin and monitoring program on the basin. Although NWMP has delineated the hydrological characteristics of eight hydrological regions in Bangladesh and has taken lot of regional programs, but the data about the human impact on the basin and the monitoring program (surface water and ground water quality and quantity) is quite inadequate and sometimes absent in hydrological regions in Bangladesh. Till to date, there is no competent authority for hydrological region basis management. Other major constraints for applying WFD in Bangladesh include the lack of coordination within the co-riparian countries, lack of physical infrastructure (communication, internet, fax, update technology), lack of quick resource mobilization and budget, lack of research, awareness and coordination among the departments. The political instability, social and environmental impact and frequent natural hazards are also the hindrance factor for implementing IWRM plan in Bangladesh as like as EU model IWRM plan.

\section{Conclusions}

After the 1990 period, the country has achieved a lot of advantage and knowledge in compliance with IWRM guideline. Although the existing policy, plan, guideline and law did not match accurately with IWRM pillars, yet the existing policy, plan, guideline and law provides a sound basis for the IWRM implementation in Bangladesh considering the principals of IWRM i.e. equity, efficiency, environmental sustainability. WARPO along with Competent Authority in each hydrological region (as like as river basin district) can play a vital role for effective implementation of IWRM in Bangladesh.

The responsibility for negotiating sharing agreements on trans-boundary rivers rests with the Joint Rivers Commission and here too, decisions are promoted that are in the best interests of all basin stakeholders. IWRM-related communication and training within Bangladesh has been strongly supported through the efforts of the Bangladesh Water Partnership, which is also playing a significant role in promoting regional cooperation on shared river basins. The study has shown that, In spite of constraints to develop IWRM plan in Bangladesh, the progress towards integrated water resources management in Bangladesh has been good. Much remains to be done. Nevertheless, advancing IWRM is a process of incremental steps and the Bangladesh water-related sector is clearly moving in the right direction towards the IWRM plan. 


\section{REFERENCES}

ADB-RETA, 2009. Regional Technical Assistance Supporting IWRM ( Bangladesh),Water Resources Planning organization, Ministry of Water Resources, Government of the People's Republic of Bangladesh.

Ahmed, S. (2008), Integrated Water Resources Management: From Policy to Practice through a Comprehensive NWMP-A case Study Bangladesh.

Annual Development Budget in Bangladesh,(www.bengaliwiki.com/page/Development+Budget)

Bangladesh Water Development Board (www.bwdb.gov.bd)

Barua, S. (2006), River Basin Management Guidelines for water management in Bangladesh.

Chowdhury , J.U. (2011), Integrated Approach and Equity Principles to promote Sustainable Water Management in Bangladesh, IWFM, BUET.

Department of Environment (www.doe-bd.org)

Department of Public Health Engineering (www.dphe.gov.bd)

Francés, F. (2011), Online questionnaire survey to ffrances@hma.upv.es on on European Water management System and Developing country like Bangladesh.

Global Partnership (www.gwp.org/en/About-GWP/History)

Global Water Partnership, 2000. Technical Advisory Committee (TAC) Background Papers, NO. 4, Integrated Water Resources Management, , SE -105 25 Stockholm, Sweden)

Interuniversitary Programme in Water Resources Engineering (IUPWARE) second year subject "Social, Political, Institutional, Economic and Environmental Aspects of Water Resources" taught by Professor, Ph. Quevauviller.

Joint River Commission, Bangladesh (www.jrcb.gov.bd)

Local Government Engineering Department (www.lged.gov.bd)

Location map of Bangladesh in World (http:/ / www.mapsofworld.com/bangladesh)

Meldrum, A. (2011), online questionnaire survey to Anita.Meldrum@gcu.ac.uk on European Water management System and Developing country like Bangladesh.

MoWR, 1999. National Water Policy, Ministry of Water Resources, Government of the People's Republic of Bangladesh.

MoWR, 2010. Draft Bangladesh Water Act, Ministry of Water Resources, Government of the People's Republic of Bangladesh.

Research projects (IWRM.Net).

United Nation Water (The Dublin statement- www.gdrc.org/ uem/water/dublin-statement),

WARPO, 2001b. National Water Management Plan, Vol.1: Summery Report, Vol.2: Main Report, Water Resources Planning organization, Ministry of Water Resources, Government of the People's Republic of Bangladesh.

WARPO, 2009. Annual Report 2007-2008, Water Resources Planning organization, Ministry of Water Resources, Government of the People's Republic of Bangladesh.

Water Resources Planning Organization (www.warpo.gov.bd)

Water resources Wikipedia (http://en.wikipedia.org/wiki/Water_resources)

WFD, 2000/60/EC. Water Framework Directive (www. ec.europa.eu/environment/water/waterframework)

\section{Why Open Access ???}

"In the traditional publishing model, readers have limited access to scientific papers; authors do not have copyright for their own papers, and cannot post their papers on their own websites, which presents a significant barrier to the sharing of knowledge, as well as being unfair to authors. Open access can overcome the drawbacks of the traditional publishing model and help scholars build on the findings of their colleagues without restriction"

ABC Journals is a unique forum to offer open access to all of its articles.

Now ABC Journal's portfolio is over nine journals, which publish both online and in print. 